\title{
Altererythrobacter marinus sp. nov., isolated from deep seawater
}

Correspondence

Zongze Shao

shaozz@163.com

\author{
Qiliang Lai, Jun Yuan and Zongze Shao
}

Key Laboratory of Marine Biogenetic Resources, Third Institute of Oceanography, State Oceanic Administration, PR China

\begin{abstract}
A taxonomic study was carried out on strain $\mathrm{H}_{3} 2^{\top}$, which was isolated from a crude-oil-degrading consortium enriched from deep seawater of the Indian Ocean. The 16S rRNA gene sequence of strain $\mathrm{H}_{3} 2^{\top}$ showed highest similarity to that of Altererythrobacter luteolus SW-109 ${ }^{\top}(96.7 \%)$; lower similarities were observed with other members of the genus Altererythrobacter (94.7$95.7 \%$ ) and with members of the genera Erythrobacter (94.5-96.3\%), Erythromicrobium (94.9\%) and Porphyrobacter (94.3-95.3\%). Phylogenetic analyses of all members of the family Erythrobacteraceae and several members of the family Sphingomonadaceae revealed that strain $\mathrm{H} 32^{\top}$ formed a clade within the genus Altererythrobacter. The dominant fatty acids were $\mathrm{C}_{16: 0}$ (6.7\%), $\mathrm{C}_{18: 1} \omega 7 c(44.3 \%)$ and 11-methyl $\mathrm{C}_{18: 1} \omega 7 c(25.4 \%)$. The major respiratory quinone was ubiquinone 10. The DNA G $+\mathrm{C}$ content was 66.5 mol\%. Strain $\mathrm{H} 32^{\top}$ did not contain bacteriochlorophyll $a$. These characteristics are in good agreement with those of members of the genus Altererythrobacter. Therefore, according to its morphology, physiology, fatty acid composition and 16S rRNA gene sequence data, strain $\mathrm{H}_{3} 2^{\top}$ belongs to the genus Altererythrobacter, but can be readily distinguished from known Altererythrobacter species. It is therefore proposed that strain $\mathrm{H} 32^{\top}$ represents a novel species, Altererythrobacter marinus

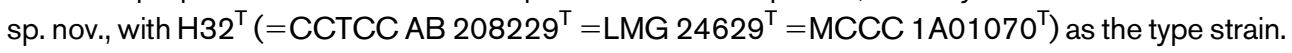

In an attempt to investigate crude-oil-degrading bacteria in deep seawater of the Indian Ocean, many bacterial strains have been isolated and characterized taxonomically (Lai et al., 2009). This study focuses on one of these isolates, designated strain $\mathrm{H} 32^{\mathrm{T}}$. Comparative $16 \mathrm{~S}$ rRNA gene sequence analysis indicated that strain $\mathrm{H} 32^{\mathrm{T}}$ formed a clade within the genus Altererythrobacter. The genus Altererythrobacter was first proposed by Kwon et al. (2007) and comprises three species with validly published names: Altererythrobacter epoxidivorans (Kwon et al., 2007), A. luteolus (Yoon et al., 2005b; Kwon et al., 2007) and A. indicus (Kumar et al., 2008). Members of the genus Altererythrobacter are non-motile and do not contain bacteriochlorophyll $a$ (BChl $a$ ) as a photosynthetic pigment. The dominant fatty acid and respiratory quinone are $\mathrm{C}_{18: 1} \omega 7 c$ and ubiquinone-10, respectively. Accordingly, the aim of the present work was to determine the exact taxonomic position of strain $\mathrm{H} 32^{\mathrm{T}}$ by using a polyphasic approach including determination of phenotypic prop-

Abbreviation: BChl a, bacteriochlorophyll a.

The GenBank/EMBL/DDBJ accession number for the 16S rRNA gene sequence of strain $\mathrm{H}^{2} 2^{\top}$ is EU726272.

Transmission electron micrographs of cells of strain $\mathrm{H}_{3} 2^{\top}$ and cellular fatty acid contents and API 20NE/API ZYM data and antibiotic susceptibility characteristics of strain $\mathrm{H}_{3} 2^{\top}$ and related strains are available as supplementary material with the online version of this paper. erties and detailed phylogenetic analysis based on $16 \mathrm{~S}$ rRNA gene sequences.

Seawater was sampled from a water depth of $1468 \mathrm{~m}$ ( $1020 \mathrm{~m}$ above the sea floor) at the site of IR-CTD9 $\left(25.3217^{\circ} \mathrm{S} 70.0405^{\circ} \mathrm{E}\right)$ on the south-west Indian Ridge in December 2005 during cruise DY-105A of R/V Da-Yang Yi-Hao. The sample was enriched with crude oil and strains were isolated on $216 \mathrm{~L}$ marine agar medium as described by Lai et al. (2009). Strain $\mathrm{H} 32^{\mathrm{T}}$ was also cultivated on $216 \mathrm{~L}$ medium for morphological and biochemical characterization.

The Gram reaction, catalase, oxidase and lipase (Tween 80) activities, $\mathrm{H}_{2} \mathrm{~S}$ production, hydrolysis of aesculin and starch, optimal growth temperature and $\mathrm{pH}$, tolerance of $\mathrm{NaCl}$, antibiotic susceptibility, general cell morphology and electron microscopy (Supplementary Fig. S1 available in IJSEM Online) were investigated as described by Lai et al. (2009). BChl $a$ was examined by registration of the in vitro absorption spectrum of a methanol extract of cells at 768$769 \mathrm{~nm}$ as described previously by Yoon et al. (2003). Other biochemical tests were carried out using API 20NE and API ZYM strips (bioMérieux) and Biolog GN2 MicroPlate panels according to the manufacturers' instructions, with the adjustment of $\mathrm{NaCl}$ concentration to $3.0 \%$ in all tests. A. indicus LMG $23789^{\mathrm{T}}$, A. epoxidivorans JCM $13815^{\mathrm{T}}$ and $A$. luteolus JCM $12599^{\mathrm{T}}$ were also tested using 
API 20NE and API ZYM strips and for antibiotic susceptibility at the same time as strain $\mathrm{H} 32^{\mathrm{T}}$. These results are given in the species description, Table 1 and Supplementary Table S2.

Genomic DNA preparation, 16S rRNA gene amplification and phylogenetic analysis using MEGA version 4 (Tamura et al., 2007) and DNAMAN (version 5.1; Lynnon Biosoft) were carried out as described by Lai et al. (2009). Evolutionary distances, calculated using the algorithm of Kimura's two-parameter model (Kimura, 1980), and clustering with the neighbour-joining method of Saitou \& Nei (1987) and the minimum-evolution method of Rzhetsky \& Nei (1992, 1993) (data not shown, as results were similar to those observed with the neighbour-joining method) were determined by using bootstrap values based on 1000 replications.

A nearly full-length $16 \mathrm{~S}$ rRNA gene sequence (1451 nt) of strain $\mathrm{H} 32^{\mathrm{T}}$ was determined and about $1325 \mathrm{nt}$ were used for sequence alignment and phylogenetic analysis. The $16 \mathrm{~S}$ rRNA gene sequence of strain $\mathrm{H} 32^{\mathrm{T}}$ showed the highest similarity to A. luteolus $\mathrm{SW}-109^{\mathrm{T}}(96.7 \%)$. $16 \mathrm{~S}$ rRNA gene sequence similarities were lower to other members of the genus Altererythrobacter (94.7-95.7\%) and members of the genera Erythrobacter (94.5-96.3\%), Erythromicrobium (94.9\%) and Porphyrobacter (94.3-95.3\%). A tree constructed using the neighbour-joining method is shown in Fig. 1. Phylogenetic analyses with all members of the family Erythrobacteraceae and several members of the family Sphingomonadaceae revealed that strain $\mathrm{H} 32^{\mathrm{T}}$ formed a distinct clade within the genus Altererythrobacter. $16 \mathrm{~S}$ rRNA gene sequence divergences between strain $\mathrm{H}_{32}{ }^{\mathrm{T}}$ and the recognized species were all $>3.3 \%$; thus, the data support the view that strain $\mathrm{H} 32^{\mathrm{T}}$ represents a novel species (Stackebrandt \& Goebel, 1994).

The major respiratory quinone of strain $\mathrm{H} 32^{\mathrm{T}}$ was ubiquinone 10, as determined by HPLC analysis according to Collins (1985). This trait is in accordance with the

Table 1. Characteristics that differentiate strain $\mathrm{H} 32^{\top}$ from type strains of Altererythrobacter species and from related genera of the family Erythrobacteraceae

Taxa: $1, \mathrm{H} 32^{\mathrm{T}}$ (data from this study); 2, A. indicus LMG $23789^{\mathrm{T}}$ (unless indicated, data from Kumar et al., 2008); 3, A. epoxidivorans JCM 13815 (Kwon et al., 2007; Kumar et al., 2008); 4, A. luteolus JCM $12599^{\mathrm{T}}$ (Yoon et al., 2005b; Kwon et al., 2007); 5, Porphyrobacter (Hiraishi \& Imhoff, 2005; Yoon et al., 2006); 6, Erythromicrobium ramosum DSM 8510 (Yurkov, 2005); 7, Erythrobacter (Yoon et al., 2004, 2005a; Shiba \& Imhoff, 2005). +, Positive; -, negative; w, weakly positive; $v$, variable reaction; $v(+/-)$, variable, with the response of the majority of strains in parentheses; ND, no data available; ND (-), no data available for the majority of strains, but negative for those for which data are available. All taxa are catalase-positive.

\begin{tabular}{|c|c|c|c|c|c|c|c|}
\hline Characteristic & 1 & 2 & 3 & 4 & 5 & 6 & 7 \\
\hline Cell shape & Rod & Rod & Ovoid-rod & Rod & Pleomorphic & Rod, branched & Rod \\
\hline Oxidase & - & - & + & + & $\mathrm{v}(+)$ & + & + \\
\hline Motility & - & - & - & - & $\mathrm{v}(+)$ & + & $\mathrm{v}(-)$ \\
\hline Presence of BChl $a$ & - & - & - & - & + & + & $\mathrm{V}(-)$ \\
\hline \multicolumn{8}{|l|}{ Hydrolysis of: } \\
\hline Aesculin & + & + & $-*$ & + & $\mathrm{v}(+)$ & $\mathrm{ND}$ & + \\
\hline Gelatin & - & $-\dagger$ & $+\dagger$ & $+\dagger$ & $\mathrm{v}(-)$ & - & $\mathrm{v}(-)$ \\
\hline Starch & - & - & $-{ }^{*}$ & $\mathrm{w}$ & $\mathrm{v}(+)$ & - & $\mathrm{v}(-)$ \\
\hline Tween 80 & + & $+\dagger$ & + & + & $\mathrm{v}(+)$ & - & + \\
\hline $\mathrm{H}_{2} \mathrm{~S}$ production & - & $-\dagger$ & - & - & $\mathrm{ND}(-)$ & ND & $\mathrm{ND}(-)$ \\
\hline \multicolumn{8}{|l|}{ Utilization of: } \\
\hline Glucose & - & + & -† & + & + & + & $\mathrm{v}(+)$ \\
\hline Fructose & - & - & $-{ }^{*}$ & - & $\mathrm{V}(-)$ & + & $\mathrm{v}(-)$ \\
\hline Acetate & + & $\mathrm{W}$ & -末 & - & $\mathrm{V}(-)$ & + & + \\
\hline Citrate & - & - & $-\ddagger$ & - & - & + & $\mathrm{v}(-)$ \\
\hline Pyruvate & + & - & $-{ }^{*}$ & + & $\mathrm{v}(+)$ & + & $\mathrm{v}(+)$ \\
\hline Glutamate & + & - & - & + & $\mathrm{v}$ & + & $\mathrm{v}(-)$ \\
\hline Succinate & - & - & - & - & $\mathrm{v}$ & + & $\mathrm{v}(+)$ \\
\hline Malate & - & + & $-{ }^{*}$ & - & $\mathrm{V}(-)$ & + & $\mathrm{v}(-)$ \\
\hline DNA G $+\mathrm{C}$ content $(\mathrm{mol} \%)$ & 66.5 & 66.8 & 54.5 & 60.3 & $63.8-66.8$ & 64.2 & $60-67$ \\
\hline
\end{tabular}

${ }^{\star}$ Data from this study; also reported as negative by Kumar et al. (2008).

$\dagger$ Data from this study.

$\ddagger$ Data from this study; reported as positive by Kumar et al. (2008). 


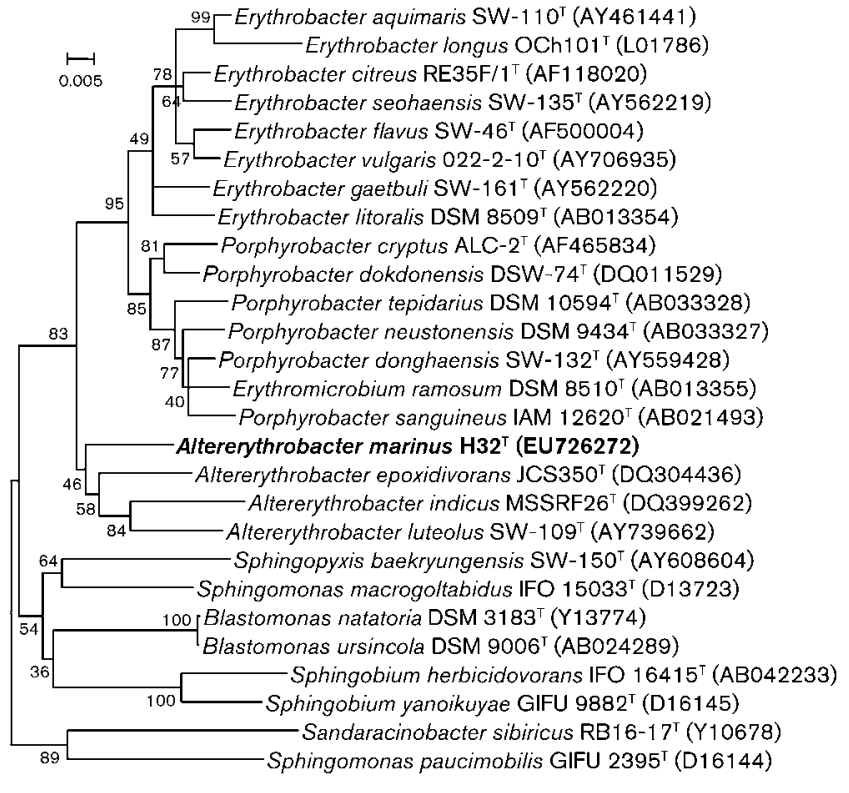

Fig. 1. Neighbour-joining tree showing the phylogenetic positions of strain $\mathrm{H} 32^{\top}$ and representatives of some other related taxa based on 16S rRNA gene sequences. Bootstrap values (expressed as percentages of 1000 replications) are shown at branch points. Bar, 0.005 nucleotide substitution rate $\left(K_{\text {nuc }}\right)$.

properties of its closest relatives (Denner et al., 2002; Yoon et al., 2003, 2004, 2005a, b; Kwon et al., 2007; Kumar et al. 2008). Fatty acids in whole cells grown on $216 \mathrm{~L}$ plate medium at $28{ }^{\circ} \mathrm{C}$ for $48 \mathrm{~h}$ were extracted, saponified and esterified; this was followed by GC analysis of the fatty acid methyl esters according to the instructions of the MIDI system (Sasser, 1990). As showed in Supplementary Table $\mathrm{S} 1$, the major fatty acids of strain $\mathrm{H} 32^{\mathrm{T}}$ were $\mathrm{C}_{18: 1} \omega 7 \mathrm{c}$ $(44.3 \%), 11$-methyl $\mathrm{C}_{18: 1} \omega 7 c(25.4 \%)$ and $\mathrm{C}_{16: 0}(6.7 \%)$. All the Altererythrobacter type strains studied and strain $\mathrm{H} 32^{\mathrm{T}}$ contained $\mathrm{C}_{14: 0} 2-\mathrm{OH}$ as the major hydroxylated fatty acid $(2.8-7.9 \%)$. The fatty acids $\mathrm{C}_{16: 0} 2-\mathrm{OH}$ and $11-$ methyl $\mathrm{C}_{18: 1} \omega 7 c$ were detected in strain $\mathrm{H}_{32}{ }^{\mathrm{T}}$, A. luteolus JCM $12599^{\mathrm{T}}$ and A. epoxidivorans JCM $13815^{\mathrm{T}}$, but not in A. indicus LMG $23789^{\mathrm{T}}$. However, strain $\mathrm{H} 32^{\mathrm{T}}$ had a greater proportion of 11 -methyl $\mathrm{C}_{18: 1} \omega 7 c(25.4 \%)$ than the other two type strains $(<8 \%)$.

The $\mathrm{G}+\mathrm{C}$ content of the chromosomal DNA was determined according to Mesbah \& Whitman (1989) using reversed-phase HPLC. The DNA G $+\mathrm{C}$ content of strain $\mathrm{H} 32^{\mathrm{T}}$ was $66.5 \mathrm{~mol} \%$, which is close to that of $A$. indicus LMG $23789^{\mathrm{T}}(66.8 \mathrm{~mol} \%)$.

Phylogenetic analysis based on 16S rRNA gene sequences confirmed that strain $\mathrm{H} 32^{\mathrm{T}}$ belonged to the genus Altererythrobacter. The clade of the genus Altererythrobacter was separated from other genera of the family Erythrobacteraceae with a bootstrap value of $46 \%$. This was supported by morphological, physiological and chemotaxonomic characteristics. Strain $\mathrm{H} 32^{\mathrm{T}}$ can be differen- tiated from members of the two closely related genera Porphyrobacter and Erythromicrobium by its cell shape, motility and the absence of $\mathrm{BChl} a$. Table 1 shows the detailed characteristics used to distinguish strain $\mathrm{H} 32^{\mathrm{T}}$ from related species. As shown in Supplementary Table S2, strain $\mathrm{H} 32^{\mathrm{T}}$ can be further differentiated from the three species of the genus Altererythrobacter by API 20NE and API ZYM data and by antibiotic susceptibility results. On the basis of its unique phenotypic traits, strain $\mathrm{H}_{32}{ }^{\mathrm{T}}$ represents a novel species within the genus Altererythrobacter, for which the name Altererythrobacter marinus sp. nov. is proposed.

\section{Description of Altererythrobacter marinus sp. nov.}

Altererythrobacter marinus (ma.ri'nus. L. masc. adj. marinus of the sea, marine).

Cells are rod-shaped (1.0-1.2 $\mu \mathrm{m}$ long and $0.4 \mu \mathrm{m}$ wide) and non-motile. On 216L agar, forms smooth yellow colonies with regular edges that are $1-2 \mathrm{~mm}$ in diameter after $72 \mathrm{~h}$ incubation at $28{ }^{\circ} \mathrm{C}$ and slightly raised in the centre. Positive for catalase, lipase (Tween 80) and hydrolysis of aesculin, but negative for Gram reaction, oxidase, amylase, urease, gelatinase, arginine dihydrolase, indole production, $\mathrm{H}_{2} \mathrm{~S}$ production, glucose fermentation and reduction of nitrate to nitrite. Growth, assessed over 7 days, is observed in $0.5-5.0 \% \mathrm{NaCl}$ (optimum $3 \%$ ) and at $10-42{ }^{\circ} \mathrm{C}$ (optimum $25-37{ }^{\circ} \mathrm{C}$ ), but not at 4 or $45{ }^{\circ} \mathrm{C}$. The major respiratory quinone is ubiquinone 10 . BChl $a$ is not detected. Principal fatty acids are $\mathrm{C}_{18: 1} \omega 7 c, 11$-methyl $\mathrm{C}_{18: 1} \omega 7 c$ and $\mathrm{C}_{16: 0}$. Sensitive to ampicillin $(10 \mu \mathrm{g}$ per disc), carbenicillin $(100 \mu \mathrm{g})$, cefalexin $(30 \mu \mathrm{g})$, cefazolin $(30 \mu \mathrm{g})$, cefobid $(30 \mu \mathrm{g})$, cephradine $(30 \mu \mathrm{g})$, chloromycetin $(30 \mu \mathrm{g})$, ciprofloxacin $(5 \mu \mathrm{g})$, co-trimoxazole $(25 \mu \mathrm{g})$, erythromycin $(15 \mu \mathrm{g})$, kanamycin $(30 \mu \mathrm{g})$, penicillin $\mathrm{G}$ $(10 \mu \mathrm{g})$, piperacillin $(100 \mu \mathrm{g})$, rifampicin $(5 \mu \mathrm{g})$, rocephin $(30 \mu \mathrm{g})$, tetracycline $(30 \mu \mathrm{g})$, vancomycin $(30 \mu \mathrm{g})$ and vibramycin $(30 \mu \mathrm{g})$. Resistant to clindamycin $(2 \mu \mathrm{g})$, furazolidone $(15 \mu \mathrm{g})$, gentamicin $(10 \mu \mathrm{g})$, lincomycin $(2 \mu \mathrm{g})$, metronidazole $(5 \mu \mathrm{g})$, minomycin $(30 \mu \mathrm{g})$, neomycin $(10 \mu \mathrm{g})$, norfloxacin $(10 \mu \mathrm{g})$, ofloxacin $(5 \mu \mathrm{g})$, oxacillin $(1 \mu \mathrm{g})$, polymyxin $\mathrm{B}(30 \mathrm{U})$ or streptomycin $(10 \mu \mathrm{g})$. In API ZYM tests, positive for alkaline phosphatase, esterase lipase (C8), leucine aminopeptidase, trypsin, valine aminopeptidase and $\alpha$-chymotrypsin; weakly positive for acid phosphatase, cystine aminopeptidase, esterase (C4), lipase (C14), naphthol-AS-BI-phosphoamidase, $\alpha$ glucosidase and $\beta$-glucosidase; and negative for $N$-acetyl- $\beta$ glucosaminidase, $\alpha$-fucosidase, $\alpha$-galactosidase, $\alpha$-mannosidase, $\beta$-galactosidase and $\beta$-glucuronidase. Of the 12 carbon substrates in the API 20NE strip, can only utilize maltose. Of the 95 carbon substrates in the Biolog system, positive for acetic acid, L-asparagine, L-aspartic acid, Lornithine, L-phenylalanine, L-threonine, $\alpha$-cyclodextrin, Tweens 40 and 80 , maltose, methylpyruvate, monomethyl succinate, $\beta$-hydroxybutyric acid, $\alpha$-ketovaleric acid, 
L-glutamic acid, glycyl L-glutamic acid, L-leucine, L-proline and L-serine.

The type strain is $\mathrm{H} 32^{\mathrm{T}}$ (=CCTCC AB $208229^{\mathrm{T}}=\mathrm{LMG}$ $24629^{\mathrm{T}}=$ MCCC $\left.1 \mathrm{~A} 01070^{\mathrm{T}}\right)$, isolated from deep seawater of the Indian Ocean. The DNA G $+C$ content of the type strain is $66.5 \mathrm{~mol} \%$.

\section{Acknowledgements}

This work was financially supported by the Scientific Research Foundation of the Third Institute of Oceanography, SOA (no. 2009065), the COMRA program (no. DYXM115-02-2-05), the National Infrastructure of Natural Resources for Science and Technology Program of China (no. 2005DKA21209), the National Basic Research Program of China (no. 2004CB719601) and the National Natural Science Foundation of China (no. 30670051).

\section{References}

Collins, M. D. (1985). Isoprenoid quinone analysis in bacterial classification and identification. In Chemical Methods in Bacterial Systematics, pp. 267-287. Edited by M. Goodfellow \& D. E. Minnikin. London: Academic Press.

Denner, E. B. M., Vybiral, D., Kobližek, M., Kämpfer, P., Busse, H.-J. \& Velimirov, B. (2002). Erythrobacter citreus sp. nov., a yellow-pigmented bacterium that lacks bacteriochlorophyll $a$, isolated from the western Mediterranean Sea. Int J Syst Evol Microbiol 52, 1655-1661.

Hiraishi, A. \& Imhoff, J. F. (2005). Genus VII. Porphyrobacter Fuerst, Hawkins, Holmes, Sly, Moore and Stackebrandt 1993, 132 VP. In Bergey's Manual of Systematic Bacteriology, 2nd edn, vol. 2, part C, pp. 275-279. Edited by D. J. Brenner, N. R. Krieg, J. T. Staley \& G. M. Garrity. New York: Springer.

Kimura, M. (1980). A simple model for estimating evolutionary rates of base substitutions through comparative studies of nucleotide sequences. J Mol Evol 16, 111-120.

Kumar, N. R., Nair, S., Langer, S., Busse, H.-J. \& Kämpfer, P. (2008). Altererythrobacter indicus sp. nov., isolated from wild rice (Porteresia coarctata Tateoka). Int J Syst Evol Microbiol 58, 839-844.

Kwon, K. K., Woo, J.-H., Yang, S.-H., Kang, J.-H., Kang, S. G., Kim, S.-J., Sato, T. \& Kato, C. (2007). Altererythrobacter epoxidivorans gen. nov., sp. nov., an epoxide hydrolase-active, mesophilic marine bacterium isolated from cold-seep sediment, and reclassification of Erythrobacter luteolus Yoon et al. 2005 as Altererythrobacter luteolus comb. nov. Int J Syst Evol Microbiol 57, 2207-2211.

Lai, Q., Yuan, J., Gu, L. \& Shao, Z. (2009). Marispirillum indicum gen. nov., sp. nov., isolated from a deep-sea environment. Int J Syst Evol Microbiol 59, 1278-1281.
Mesbah, M. \& Whitman, W. B. (1989). Measurement of deoxyguanosine/thymidine ratios in complex mixtures by high-performance liquid chromatography for determination of the mole percentage guanine + cytosine of DNA. J Chromatogr 479, 297-306.

Rzhetsky, A. \& Nei, M. (1992). A simple method for estimating and testing minimum-evolution trees. Mol Biol Evol 9, 945-967.

Rzhetsky, A. \& Nei, M. (1993). Theoretical foundation of the minimum-evolution method of phylogenetic inference. Mol Biol Evol 10, 1073-1095.

Saitou, N. \& Nei, M. (1987). The neighbor-joining method: a new method for reconstructing phylogenetic trees. Mol Biol Evol 4, 406425.

Sasser, M. (1990). Identification of bacteria by gas chromatography of cellular fatty acids. MIDI Technical Note 101. Newark, DE: MIDI Inc.

Shiba, T. \& Imhoff, J. F. (2005). Genus IV. Erythrobacter Shiba and Simidu 1982, 215 ${ }^{\mathrm{VP}}$. In Bergey's Manual of Systematic Bacteriology, 2nd edn, vol. 2, part C, pp. 267-268. Edited by D. J. Brenner, N. R. Krieg, J. T. Staley \& G. M. Garrity. New York: Springer.

Stackebrandt, E. \& Goebel, B. M. (1994). Taxonomic note: a place for DNA-DNA reassociation and 16S rRNA sequence analysis in the present species definition in bacteriology. Int J Syst Bacteriol 44, 846849.

Tamura, K., Dudley, J., Nei, M. \& Kumar, S. (2007). MEGA4: molecular evolutionary genetics analysis (MEGA) software version 4.0. Mol Biol Evol 24, 1596-1599.

Yoon, J.-H., Kim, H., Kim, I.-G., Kang, K. H. \& Park, Y.-H. (2003). Erythrobacter flavus sp. nov., a slight halophile from the East Sea in Korea. Int J Syst Evol Microbiol 53, 1169-1174.

Yoon, J.-H., Kang, K. H., Oh, T.-K. \& Park, Y.-H. (2004). Erythrobacter aquimaris sp. nov., isolated from sea water of a tidal flat of the Yellow Sea in Korea. Int J Syst Evol Microbiol 54, 1981-1985.

Yoon, J.-H., Oh, T.-K. \& Park, Y.-H. (2005a). Erythrobacter seohaensis sp. nov. and Erythrobacter gaetbuli sp. nov., isolated from a tidal flat of the Yellow Sea in Korea. Int J Syst Evol Microbiol 55, 71-75.

Yoon, J.-H., Kang, K. H., Yeo, S.-H. \& Oh, T.-K. (2005b). Erythrobacter luteolus sp. nov., isolated from a tidal flat of the Yellow Sea in Korea. Int J Syst Evol Microbiol 55, 1167-1170.

Yoon, J.-H., Kang, S.-J., Lee, M.-H., Oh, H. W. \& Oh, T.-K. (2006). Porphyrobacter dokdonensis sp. nov., isolated from sea water. Int J Syst Evol Microbiol 56, 1079-1083.

Yurkov, V. V. (2005). Genus V. Erythromicrobium Yurkov, Stackebrandt, Holmes, Fuerst, Hugenholtz, Golecki, Gad'on, Gorlenko, Kompantseva and Drews 1994c, 432 ${ }^{\mathrm{VP}}$. In Bergey's Manual of Systematic Bacteriology, 2nd edn, vol. 2, part C, pp. 268273. Edited by D. J. Brenner, N. R. Krieg, J. T. Staley \& G. M. Garrity. New York: Springer. 